\title{
画像解析を応用したゴム材料の 破断特性の把握とモデル化
}

\author{
吉田純司 ${ }^{1} \cdot$ 阿部雅人 ${ }^{2} \cdot$ LEWANGAMAGE Chamindaral Sujeewa ${ }^{3} \cdot$ 藤野陽三 $^{4}$ \\ ${ }^{1}$ 正会員 博士(工) 山梨大学講師 工学部土木環境工学科 ( $\bar{\top} 400-8511$ 山梨県甲府市武田 4-3-11) \\ ${ }^{2}$ 正会員 Ph.D. 東京大学助教授 工学系研究科 社会基盤工学専攻 \\ ( $\bar{T} 113-8656$ 東京都文京区本郷 7-3-1) \\ 3 学生員 修士(工) 東京大学 工学系研究科 社会基盤工学専攻（同上） \\ ${ }^{4}$ フェロー会員 Ph.D. 東京大学教授 工学系研究科 社会基盤工学専攻（同上）
}

\begin{abstract}
ゴム材料は，積層ゴム支承などの免震デバイスの主材料として広く応用されている，そのため，材 料の破断特性を把握することは構造物全体の限界を知る上で重要な要素となる. 本研究ではゴム材料 の破断特性を把握し，破断を予測するためのモデルを構筑することを目的とする．まずゴム材料の破 断試験を行い, 画像計測手法を利用して破断時の変形を詳細に把握する. 次いで材料試験結果を基に, ゴム材料の破断を予測するためのモデルを提案する，さらに，本破壊基準を積層ゴム支承に適用した 場合の妥当性を, 画像計測結果ならびに有限要素モデルによるシミュレーション結果により検証する. 最後に提案した破壊基準を応用し, 積層ゴム支承の破断を評価するための解析解を提案する.
\end{abstract}

Key Words: rubber material, failure criterion, image processing, strain invariant, design equation, laminated rubber bearing, finite element analysis

\section{1. はじめに}

1995 年兵庫県南部地震以降, 構造物の耐震性能 を向上させるために積層ゴム支承に代表される免 震・制振デバイスを採用している建築構造物や橋梁 が増加してきている ${ }^{1), 2)}$ ，積層ゴム支承は，微圧縮 性を有するゴム材料と, 鋼を交互に積層状に接着し た構造部材である。この構造形式によりゴムの体積 変形を拘束することで構造部を鉛直方向に剛に支 持している，一方で，水平方向に対しては柔軟性を 有し地震時における構造全体の損傷を支承部に局 在化することを企図している，そのため，支承部に 極度な大変位が生じ破断に至る場合には, 他の意図 しない箇所に損傷が生じる, あるいは構造物全体が 倒壊する, 等の可能性を有している.このことから, 支承の破断特性を把握することは, 免震構造物の限 界を予測し信頼性・安全性の高い設計を行う上で重 要な要素の一つとなる. 実際の支承の使用を考える と, 大地震時に単調な大変位が作用する, あるいは 繰り返し載荷による低サイクル疲労が原因で破壊 に至ることが考えられる。既往の研究では, 主に支 承レベルにおいて地震時挙動を反映した載荷条件 により破断実験を行い破断特性を検討 ${ }^{3), 4), 5)}$ してい る.しかし，支承レベルでの実験であることから，
支承の形状や使用されているゴム材料が異なると 破断特性も変化し, これらの実験結果を設計に応用 することは困難となる.

現在の設計では, 疲労の影響は考慮せず, 経験的 に支承レベルでの破断変位を定め, 支承の限界性能 を規定している ${ }^{6)}$. しかしこの限界值は，理論的な 根拠がなく, 信頼性が高いとはいい難い.また，ゴ ム材料の耐力を検查することを目的として, 個別に 引張り破断試験を義務づけているものの, 材料レべ ルでの破壊を予測するモデルがないことから, 支承 レベルでの設計と定量的に結びついていない. 従っ てこれらの影響を反映し合理的な設計を行うため には，材料レベルから支承の破断を予測可能なモデ ルが必要となる.

一方，高分子材料では，ガラスなど脆性的な材料 について破壊に関する研究が行われているものの ${ }^{7)}$, 延性に富むゴム, プラスチックなどに関してはほと んど検討されていない ${ }^{8), 99}$.この主たる理由として, 延性に富む材料は，大変形し数百\%の大ひずみを生 じるため, それを計測する手段が存在しなかったこ とが挙げられる。そのため, ゴム材料の破断限界を モデル化するためのデータが全く得られていない のが現状である.

そこで本研究では, 画像解析を応用してゴムの破 


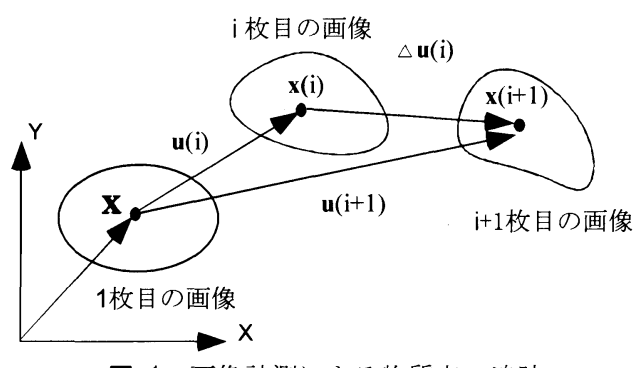

図-1 画像計測による物質点の追跡

断特性を把握し，その結果を基に材料および積層ゴ 厶支承の破壊を予測するためのモデルを構築する ことを目的とする.

まず, 材料の変形を把握するために用いた画像解 析手法 ${ }^{10)}$ の概要を説明する. 特にここでは Lagrange 座標系での変形を対象として, 連続の式に基づく計 測結果の新たな補正手法を提案する.

次にゴムの破断特性を把握するために, 引張り試 験およびせん断試験を対象に単調載荷による破断 試験を行う.ただし, 本実験では, 変位-荷重関係を 得るのみならず, 試験片の変形場を画像により詳細 に把握している.

次いで, 材料試験結果を基に, ゴム材料の破壊を 予測するためのモデルを提案する. 本モデルはひず みの不変量を用いたモデルであり, 従来の引張り試 験結果から同定可能である.

さらに積層ゴム支承の有限要素モデル ${ }^{11)}$ に提案 した破壊基準を取り入れ，シミュレーションを行っ た結果と, 支承の破断実験結果との比較を行い, 本 モデルの妥当性を検討する.

最後に著者らがこれまでに構築した積層ゴム支 承の回転変形, 鉛直変形に関する解析解 ${ }^{11)}$ と, 破壊 基準を組み合わせて, 積層ゴム支承の圧縮せん断変 形におけるひずみ場を解析的に得, それを用いて支 承の破断を簡易的に判定する式を提案する.

\section{2. 画像解析を応用した計測手法}

\section{(1) マッチング法 ${ }^{10)}$}

本計測システムでは, 計測する物質点を初期の画 像において定義し, それを順次追跡することで, 変 位場を計測する。

具体的には, 計測対象の変形過程を一連の画像に 記録し, 連続する 2 つ画像を比較することで画像

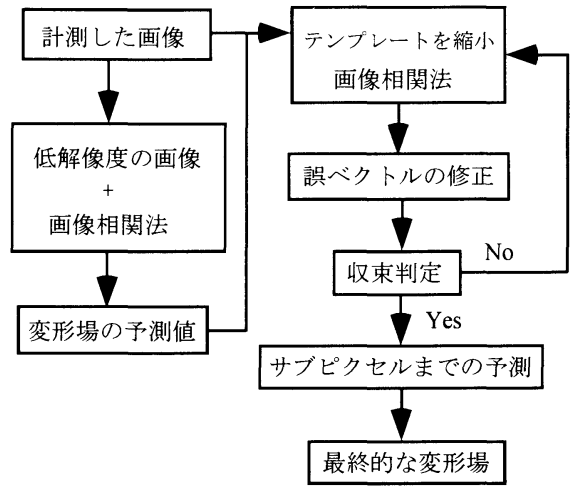

図-2＼cjkstart画像計測アルゴリズム

間における変形の増分 $\Delta \mathbf{u}$ を逐次計算していく。こ の物質点を追跡するプロセスの概念図を図-1 に示 す. 画像同士を比較する手法としては, 相関係数を 評価指標とする画像相関法を用いている，また, 誤 差の蓄積および誤ベクトルの出現を極力抑えるた めに，テンプレートのサイズを更新して繰り返し計 算する手法, およびサブピクセルまで追跡する画像 相関法を用いている. 実際の解析において用いたア ルゴリズムのチャートを図-2 に示す. 本手法の妥当 性および精度については, 文献 10）を参照されたい.

\section{（2）連続の式を用いた計測誤差の補正}

画像計測では，画素のサイズが有限であることか ら量子誤差の影響を受ける. そのため, 計測対象が 連続体であっても計測結果は, 連続の式を満足しな い. そこで以下では, 計測結果を連続の式を満足す るよう補正する手法を提案する。

質量保存則に従うと連続の式は, 以下のようにな る.

$$
\phi(\rho, \dot{\mathbf{u}})=\frac{\partial \rho(\mathbf{x}, t)}{\partial t}+\operatorname{div}(\rho \dot{\mathbf{u}})=0
$$

ここに $\rho, \mathbf{x}, \dot{\mathbf{u}}$ および $t$ は，それぞれ質量密度， 現時刻における物質点の位置べクトル，速度ベクト ルおよび現時刻である。ここで，ゴム材料はほぼ非 圧縮とみなすことができるため, それを式(1)に導入 すると連続の式は次式と等価になる。

$$
J=1
$$

ここにJは変形勾配テンソル $\mathbf{F}$ の determinant であ る. 本研究では, 式(2)の拘束条件式として, 以下の 関数 $\Phi$ を最小にする変位場を算出する.

$$
\Phi=\frac{1}{2} \sum_{k=1}^{m}\left(\tilde{\mathbf{u}}^{(k)}-\mathbf{u}^{(k)}\right)^{2}
$$

ただし $\tilde{\mathbf{u}}^{(k)} ， \mathbf{u}^{(k)}$ は，それぞれ凸領域を形成する $m$ 個 の物質点における補正後および補正前の変位べク トルである.これら $m$ 個の物質点において式(3)を拘 


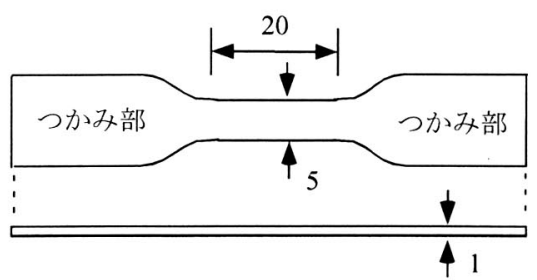

(a) 引張り試験片

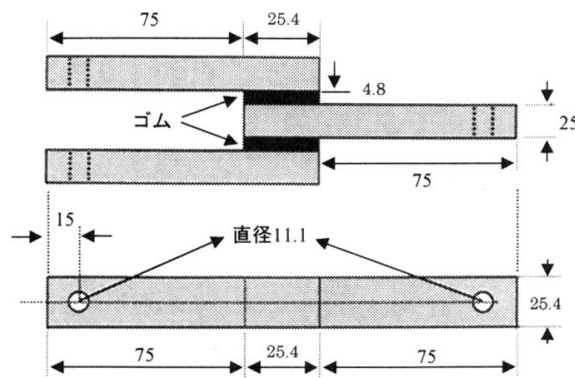

(b) せん断試験片

図-3 引張り試験片およびせん断試験片の概略図

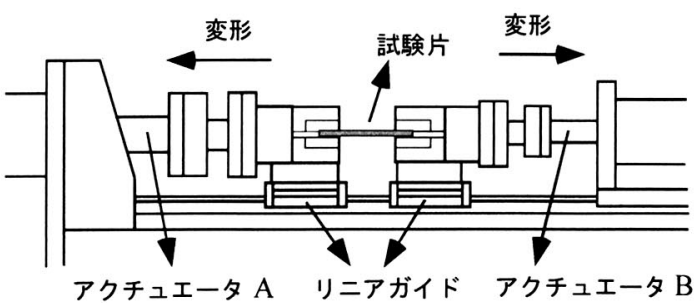

図-4 引張り試験で用いた載荷装置 (側面図)
束条件式として Lagrange の未定乗数法に導入し, 新 たな関数 を定義する.

$$
\Pi=\Phi+\sum_{k=1}^{m} \mu_{k}\left(J^{(k)}-1\right)
$$

ただし $\mu_{k}$ は, Lagrange の未定乗数であり, $J^{(k)}$ は各 物質点における $J$ の值である，変位場の補正におい ては, 式(4)を停留する $\tilde{\mathbf{u}}^{(k)}$ を求めた。具体的な計算

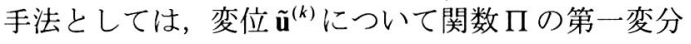
$\delta \Pi$ を得,

$$
\delta \Pi=0
$$

を離散化する. 離散化においては， $m$ 個の物質点に 囲まれた領域における変位場を適当な関数により 内挿する ${ }^{12)}$. ただし，式(5)をそのまま離散化すると 非線形方程式となる。そこで式(5)の時間導関数 $\delta \dot{\Pi}=0$ から領域ごとの増分方程式を導出する. 次い で全領域について各要素レベルでの増分方程式を 解き増分 $\Delta \tilde{\mathbf{u}}^{(k)}$ を求める操作を, 変位増分が十分小 さくなるまで繰り返し計算し, 変位 $\tilde{\mathbf{u}}^{(k)}$ を求める ${ }^{13)}$.

本手法は, 主に流体の可視化に応用されている従 来の手法 ${ }^{14)}$ と異なり, Lagrange 座標系において定義 される物質点の変形を対象としている。 また, 各領 域における補正式を各々解き，それを全体について 収束計算を行っている. そのため, 大規模な問題に おいても, 数值的に安定して解を得ることが可能で ある.また， $m$ 個の物質点に囲まれた領域の個数を $N$ とすると, 文献 10）の手法では, 計算時間が $N^{2} に$

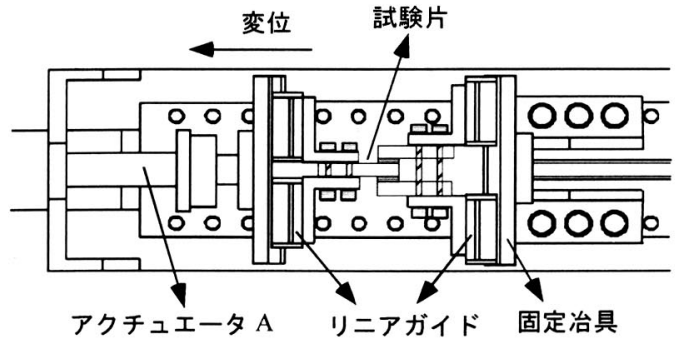

図-5 せん断試験で用いた載荷装置（平面図）

比例するのに詨し, 本手法では $N$ に比例する. その ため, 本手法の方が相詨的に計算時間が短い.

\section{3. ゴム材料の破断実験}

ゴム材料の破断特性を把握し, モデル化するため に，材料の破断試験を行う．本試験では従来のダン ベル片による引張り試験に加え, 積層ゴム支承の変 形に似通ったせん断試験を行い，2つの異なる変形 から材料の破断特性を検討する。

以下では, まず本研究におけるゴム材料の破断の 定義を述べ, 次いで破断試験の内容, 結果および考 察について記述する。

\section{（1）破断の定義}

本研究において, ゴム材料の破断とは，変形ある いは荷重を与えた場合に最初にクラックが入る状 態を示すこととする.

\section{（2）試験片}

引張り試験およびせん断試験に用いた試験片の 概略図をそれぞれ図-3に示す.

図-3(a)の引張り試験片は，JIS で規格されている ダンベル状 3 号形試験片である ${ }^{15)}$.

一方, せん断試験は，現在の日本では行われてい ないものの AASHTO におけるゴムの検査試験とし 
表-1 画像計測デバイスの性能

\begin{tabular}{|c|c|c|}
\hline 区分 & アナログカメラ & CCD メラ \\
\hline 空間解像度 & フィルムサイズ : $6 \times 4.5[\mathrm{~cm}]$ & 画素数 : $1300 \times 1000$ [pixel] \\
\hline 時間解像度 [frame $/ \mathrm{sec}]$ & 1 & 30 \\
\hline 記録方法 & フィルム & ハードディスク \\
\hline デジタル化 & $\begin{array}{c}\text { フィルムスキャナー } \\
\text { 解像度 : } 4000[\mathrm{dpi}]\end{array}$ & \\
\hline 画像ファイル形式 & 8 bit グレースケール bitmap & 8bit グレースケール bitmap \\
\hline
\end{tabular}

表-2 引張りおよびせん断における破断実験の条件

\begin{tabular}{|c|c|c|}
\hline & 引張り試験 & せん断試験 \\
\hline 載荷速度 $[\mathrm{mm} / \mathrm{sec}]$ & $1.33,2.67,5.33$ & $0.024,0.048,0.24,0.48$ \\
\hline ひずみ速度 $[\% / \mathrm{sec}]$ & $6.65,13.4,28.4$ & $0.50,1.0,5.0,10$ \\
\hline 試験片個数 & 各載荷速度で 2 個以上 & 各載荷速度で 2 個以上 \\
\hline 試験温度 $\left[{ }^{\circ} \mathrm{C}\right]$ & $20 \sim 25$ & $12 \sim 14$ \\
\hline
\end{tabular}

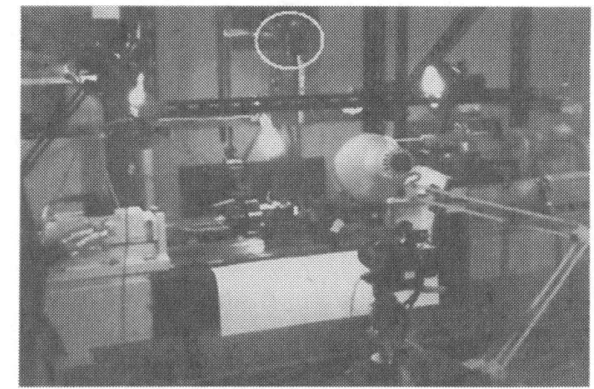

図-6 破断試験時の実験状況（図中白丸はカメラ）

て規格されているものであり ${ }^{16)}$, 本研究においても 同様の試験片を用いている.

\section{（2）実験装置}

\section{a）載荷装置}

引張り試験においては, 破断に至る試験片の伸び が非常に大きく，1台のアクチュエータを利用した だけでは, ストロークが十分ではなかった，そこで， 図-4のように 2 つのアクチュエータにより同一速 度で両側から引張り変形を与える形式で試験を実 施した. 載荷装置では, アクチュエータの中心軸と 平行にリニアガイドを設置し, それに試験片を固定 する治具を取り付けている. そのため, 材料試験に おいて試験片に回転やねじれを与えることなく，試 験片の中心軸に沿って荷重を載荷することが可能 である。

一方, せん断試験では, 図-5に示すような装置を 用いて載荷を行った。本装置では, 試験片にねじれ 変形が生じないようリニアガイドによりアクチュ エータの中心軸の回転を拘束している.

図-5における 2 つアアクチュエータは, アクチュ
エータ A が荷重容量 $\pm 20[\mathrm{kN}]$, 最大ストローク $100[\mathrm{~mm}]$ のものであり, アクチュエータ B が荷重容 量 $\pm 10[\mathrm{kN}]$, 最大ストローク $\pm 100[\mathrm{~mm}]$ である.

\section{b) 計測デバイス}

ゴム材料の破断に至る変形を精緻に把握するた め, 画像による計測を行う. 後述するが比較的低速 度での載荷においては, 空間的な解像度が高いアナ ログカメラを用いる. また, 高速度で載荷を行う場 合には, 時間分解能の高い CCD カメラを用いてい る. 両デバイスの性能を表-1 に示す.

\section{（4）実験方法}

引張りおよびせん断試験においては，異なる載荷 速度による変形を一定速度で与え, ゴムの破断特性 を把握した，各試験においての載荷速度, 試験片の 個数，ならびに試験時の温度を表-2に示す.

なお，実験においては, カメラを試験片の鉛直上 方に設置し計測を行っている．試験時の様子を図-6 に示す.

\section{（5）実験結果と考察}

\section{a)引張り試験}

引張り試験では, 中心部分が主として変形し, あ る限界まで変形すると亀裂が一瞬で進展し, 破断に 至る。そのため, 亀裂の進展を計測することができ ず, 破断時の変形は直前に得られた画像計測結果か ら判定した。

図-7に引張り試験において破断時に画像計測さ れた引張りひずみ場を示す. また, 図-8に破壊直前 における破断位置での伸び比とひずみ速度の関係 を示す.ただし図-8においてひずみ速度とは, 伸び 


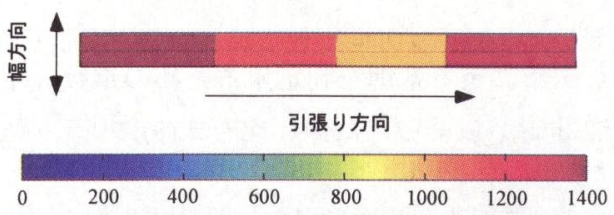

図-7 引張り試験において破断時に試験片中心部に生じ た引張り方向の Green-Lagrange ひずみ[\%]

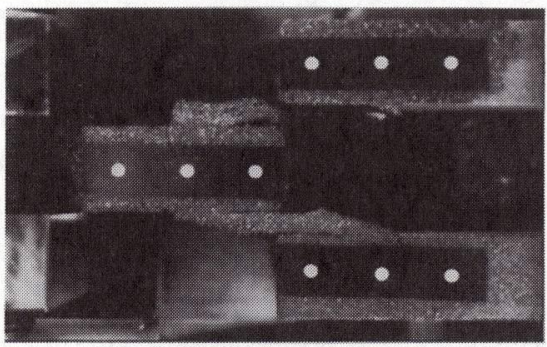

図-9 せん断試験片の破断

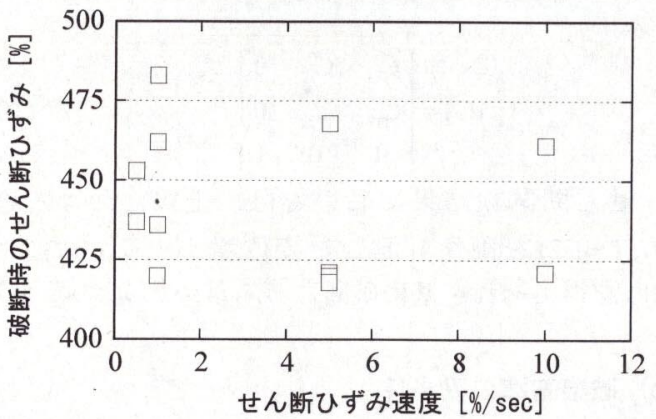

図-11 せん断試験における破断ひずみ

比の時間導関数を示す. 図-7 を見ると試験片中心部 は, 引張り方向においてひずみの分布にばらつきが あるものの，幅方向には概ね一様に変形している. なお, 図-7において計測点の数が少ないのは, 大変 形下では試験片の幅が極端に小さくなり幅方向に 含まれる画素数が少なくなることから，測定点を多 く設置できないためである.

図-8 をみると破断時の伸び比は, ひずみ速度の増 加に対し破断時の伸び比が減少していることがわ かる。.しかし，その差は試験結果全体の平均値 4.95 前後に最大 $5 \%$ 程度と非常に小さい。 また破断は, ダンベル試験片の幅が小さい中心部で発生したも のの, 必ずしも試験片の完全な中心で起こるとは限 らず，試験片によりその場所は異なる結果となった。 このことは, 試験体の形状あるいは材料自身が実際

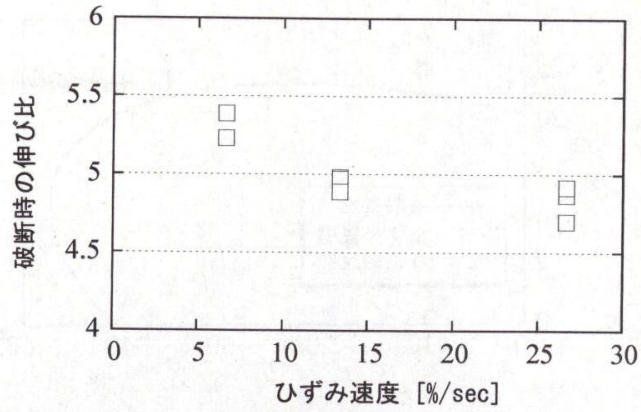

図-8 引張り試験における破断ひずみ

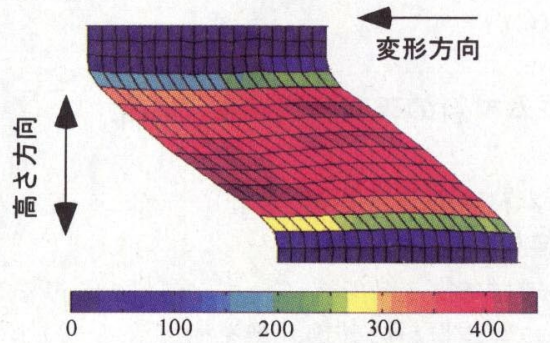

図-10 せん断試験において破断時に試験片に生じたせん 断ひずみ場 (\%)

の製作過程においてわずかな差を有しており，最も 力学的に弱い部分から破断に至ったものと考えら れる.

\section{b) せん断試験}

せん断試験においては，接着面付近に大きなひず みが生じその部分から亀裂が進展する. ただし，引 張り試験と異なり, 刍裂は少しずつ進展し最終的に は，ゴム層内部に入り込んで完全な破壊に至る。図 -9に試験片が完全に破壊に至った際の状態を示す.

また，図-10にせん断試験において破断時に画像 計測されたひずみ場を，図-11に亀裂が入る直前に おける破断位置でのひずみを示す。

図-10 を見ると上述したように上下端部に大きな 変形があることがわかる，そのため，試験片に亀裂 が最初に生じるのはこの部分となる.一方, 図-11 をみると破断位置でのひずみは, 引張り試験の場合 と同様に試験片により最大 $10 \%$ 程度のばらつきを 有していることがわかる。また，破断ひずみは，粘 塑性体や金属と異なり, 必ずしも載荷速度の大きい 場合に，小さいひずみで破断に至るとは限らないこ とがわかった。このことは, 破断特性のひずみ速度 への依存性がほとんどないことを示している。

以上の結果より，ゴム材料の破断は，速度に対す る依存性が軽微であり，また試験片によりばらつき が存在することがわかった．以下に示す破壊基準の 構築においては, この影響を考慮して行う. 


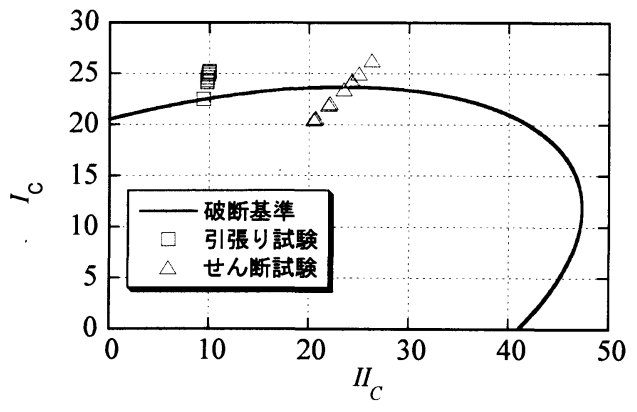

図-12 破壊基準曲線と試験結果の比較

\section{4. ゴム材料の破断特性のモデル化}

\section{（1）ゴム材料の破壊基準}

\section{a) 破壊基準}

ここでは本文 3 節で述べたゴム材料の破断試験結 果を基にゴム材料の破壊基準を構築する．以下では, ゴムに現れる破断が等方性であることを仮定して モデル化を行う.

まず，実験結果より破断は，載荷ひずみ速度に対 する依存性がない，また，破断を単調な変形により 定義していることから, 過去に経験した応力やひず みは破断に影響しないものとみなすことができる. このことから破断は破断時の変形量に依存するも のであると仮定する.このとき破壊基準は以下のよ うな右 Cauchy-Green テンソルの不変量の関数とし て表現することができる ${ }^{17)}$.

$$
W_{d}\left(I_{C}, I I_{C}, I I I_{C}\right) \leq A_{F}^{2}
$$

ただし $I_{C}, I I_{C}$ および $I I I_{C}$ は，それぞれ右 CauchyGreen テンソルの第 1 , 第 2 および第 3 不変量であ る. また, 式(6)右辺の $A_{F}$ は, 個々の材料試験から 決定される材料定数である. さらに既往の載荷実験 結果から, 積層ゴム支承などが高圧縮荷重下におい ても，ゴム層内部で破断に至らないことを考慮して， ゴム材料の破断は，実用上圧力に依存しないものと 考える.このとき式(6)は圧力に関連する $I I I_{C}$ と独立 したものとなる. さらに式(6)の $W_{d}$ をできる限り簡 潔に表現するために， $I_{C}$ および $I_{C}$ の多項式に限定 し, 次数の小さい項の組み合わせから実験結果と一 致するように選択した. 具体的な破壊基準は, 以下 に示すようなものである.

$$
W_{d}=\left(I_{C}-3\right)^{2}+\left(I I_{C}-3\right)^{2}-\left(I_{C}-3\right)\left(I I_{C}-3\right) \leq A_{F}^{2}
$$

\section{b) 材料試験における破断の判定}

次いで式(7)を材料試験でのひずみ場に適用し, 引 張り状態および単純せん断状態での破断を判定す る式を導出する. まず, 引張り試験のひずみ場 ${ }^{17), 18)}$
に式(9)を適用すると破壊基準は以下のように記述 できる.

$$
W_{d}=\lambda^{4}-2 \lambda^{3}+\lambda^{2}-2 \lambda+4 \leq A_{F}^{2}
$$

ただし $\lambda$ は引張り方向の伸び比である. 引張り変形 から破断に至る基準を判定するための定数 $A_{F}$ は, 画像計測から得られた伸び比を式(8)に代入して求 めた.

一方, 単純せん断変形におけるひずみ場 ${ }^{17), 18)}$ を式 (7)に代入すると, 破壊基準は以下のような簡潔な式 で記述できる。

$$
W_{d}=\gamma^{4} \leq A_{F}^{2}
$$

ただし $\gamma$ は水平方向の変形量を試験片の高さで除 した值であり, 本研究ではこれをせん断ひずみと呼 ぶことにする．なお，材料試験においては破断に至 る水平方向の変位が非常に大きく, 実際に破断が起 こる端部において変形が単純せん断変形により精 度よく近似できるとは言い難い.このことは図-10 に示すせん断変形からもわかる.

本研究では, 単純せん断試験におけるひずみ場を 平面ひずみ場と考えた，平面ひずみ場において，右 Cauchy - Green テンソルは, 以下のように記述でき る.

$$
[C]=\left[\begin{array}{ccc}
C_{11} & C_{12} & 0 \\
C_{12} & C_{22} & 0 \\
0 & 0 & 1
\end{array}\right]
$$

せん断試験結果においては, 上式における $C_{i j}$ $(i, j=1,2)$ を画像計測した変位場から算式(7)より $W_{d}$ を得, それを基に破断に至る最小の $A_{F}$ の值を算 出した.

\section{c）破壊基準の妥当性}

図-12 に提案した破壊基準において等号が成立す る場合の曲線を， $I_{C}$ および $I I_{C}$ に対して図示したも の, ならびに各材料試験において式(8)および式(10) より得られた破断時の $\sqrt{W_{d}}$ の值を示す. ただし, 材 料が破断に至るひずみ量は, 前述したようにばらつ きがあり，試験結果から得られる $A_{F}$ の值は $17.1 \leq A_{F} \leq 22.8$ のように一定の幅を有する.ここで は $A_{F}$ の值として, 平均値 20.5 を用いている. 図-12 をみると，破断曲面はせん断試験結果から得られた ものであるが, 引張り試験における破断時の $\sqrt{W_{d}}$ の 值も曲面に近いところにあることがわかる.

ただし，現段階においては，引張り試験およびせ ん断試験の結果のみを対象としており,ここで提案 したモデルを検証するための実験データが十分と はいい難い. 今後, 一般 2 軸引張り試験等を実施し, 多軸変形状態で破壊に至る場合について, 本モデル の妥当性を検討してく予定である. 


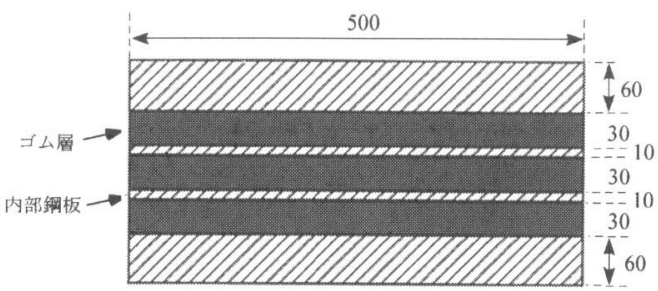

図-13 破壊実験の対象とした積層ゴム支承の断面図

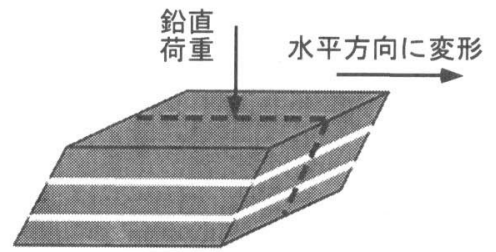

図-14 積層ゴム支承の変形

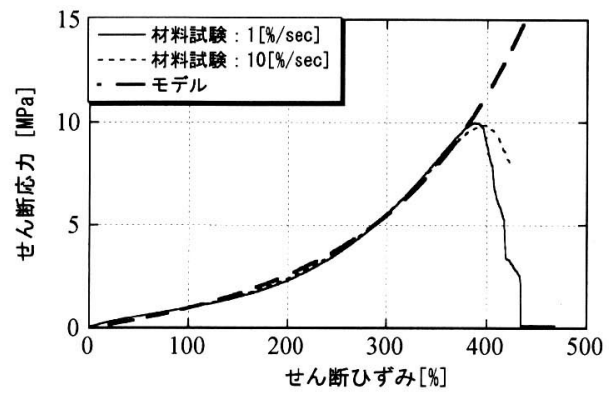

図-15 せん断試験結果と，構成則による解析結果の比較

\section{（2）積層ゴム支承の破断実験結果との比較}

前述したようにゴム材料は, 免震・制振デバイス として積層ゴム支承に広く利用されている。ここで は, 提案したモデルを積層ゴム支承に適用した場合 の妥当性を検証する. 具体的には積層ゴム支承の破 断実験を行い, 実験結果と有限要素モデルを用いた 解析結果を比較して，提案した破壊基準の妥当性を 検討した。

\section{a）積層ゴム支承の破断実験}

本実験において対象とした支承は，図-13 に示す ように平面寸法 $500 \times 500$ の矩形断面を有する積層 ゴム支承である.支承の主な諸元を表-3に示寸．こ の積層ゴム支承で用いている天然ゴム材料は, 本文 3 節で述べた材料の破断実験で用いているものと同 一配合のものである.

載荷実験においては，まず，鉛直荷重を 1471.5 [kN]（面圧 5.88 [MPa]に相当）を準静的に加え，そ の後, 水平変形を $1[\mathrm{~mm} / \mathrm{sec}]$ の一定速度で支承が破 断するまで単調載荷した.
表-3 破断実験に用いた積層ゴム支承の諸元

\begin{tabular}{|c|c|}
\hline ゴム材料 & 天然ゴム \\
\hline せん断弾性係数 [MPa] & 0.98 \\
\hline 平面寸法 $[\mathrm{mm}]$ & $500 \times 500$ \\
\hline ゴム層厚 $[\mathrm{mm}]$ & 30 \\
\hline ゴム層数 & 3 \\
\hline 内部鋼鈑厚 $[\mathrm{mm}]$ & 10 \\
\hline 内部鋼板の材料種別 & $\mathrm{SS} 400$ \\
\hline 被覆ゴム & なし \\
\hline
\end{tabular}

表-4 有限要素解析での要素分割

\begin{tabular}{|c|c|}
\hline 平面方向の要素数 & $14 \times 7$ \\
\hline ゴム層の厚さ方向の要素数 & 7 \\
\hline 鋼板の厚さ方向の要素数 & 1 \\
\hline 総要素数 & 2254 \\
\hline 総自由度 & 10698 \\
\hline
\end{tabular}

表-5 ゴム材料の構成則に用いた材料定数

\begin{tabular}{|c|c|}
\hline$c_{1}\left[\mathrm{~N} / \mathrm{mm}^{2}\right]$ & $2.90 \times 10^{-1}$ \\
\hline$c_{2}\left[\mathrm{~N} / \mathrm{mm}^{2}\right]$ & $6.00 \times 10^{-4}$ \\
\hline$c_{3}\left[\mathrm{~N} / \mathrm{mm}^{2}\right]$ & $1.75 \times 10^{-1}$ \\
\hline$c_{4}\left[\mathrm{~N} / \mathrm{mm}^{2}\right]$ & 1.00 \\
\hline$c_{5}$ & $8.00 \times 10^{-2}$ \\
\hline$n$ & 1.45 \\
\hline$m$ & $8.50 \times 10^{-1}$ \\
\hline$K$ & 3.03 \\
\hline
\end{tabular}

計測は, 変位計により支承の水平変位, 鉛直変位 を計測した. また，破断時の局所的な変形を把握す るため, 支承の側面から表-1に示したアナログカメ ラにより画像計測を行った.

\section{b) 有限要素解析}

ここでは，上述した支承レベルでの破断実験結果 と, 提案した破壊基準を用いた数値計算結果を比較 することで，本破壊基準の妥当性を検証する.

具体的には, 式(7)を著者らが構築した積層ゴム支 承の有限要素モデル ${ }^{11}$ に組み込み, 実験と同一条件 の解析を行って支承の破断を数値計算により予測 した．ただし支承の変形は，図-14 の点線に示すよ うに, せん断変形と直角方向において対称になる. そこで本研究では, $1 / 2$ 部分のみモデル化し, 表-4 に示す要素分割で解析を行った. 要素は, ゴム材料 に変位節点 8, 圧力節点 1 の 6 面体混合型要素を, 鋼に変位節点 8 の 6 面体要素を用いている.また, 鋼は弾塑性体としてモデル化し, 種別が SS400 であ ることから文献 11)に示した材料定数を用いている. 


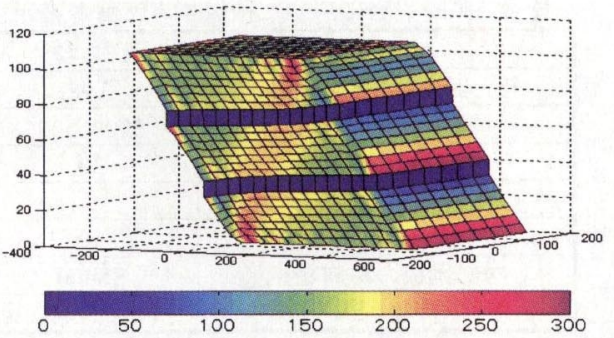

図-16 有限要素解析による積層ゴム支承の 破断時における $W_{d}$ の值

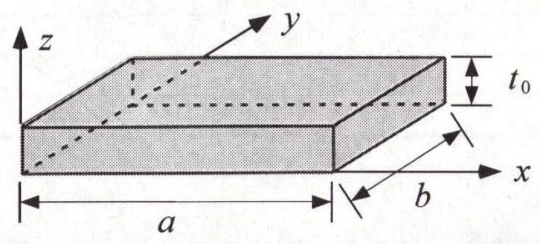

図-18 対象とするゴム層の初期形状

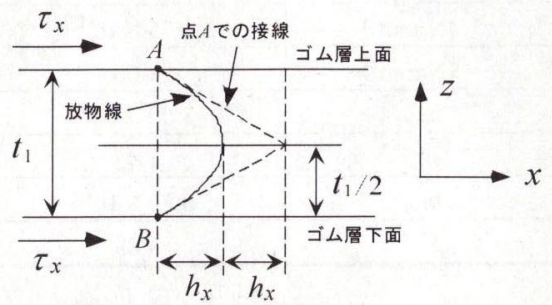

図-20 ゴム層の上下端面に生じるせん断変形

一方，ゴム材料は，以下のようなエネルギー密度関 数Wを有する超弾性体としてモデル化した.

$$
\begin{aligned}
W= & c_{4}\left[1-\exp \left\{-c_{5}\left(I_{C}-3\right)\right\}\right]+c_{1}\left(I_{C}-3\right)+ \\
& c_{2}\left(I I_{C}-3\right)^{K}+\frac{c_{3}}{n+1}\left(I_{C}-3\right)^{n+1}\left(I I_{C}-3\right)^{-m}
\end{aligned}
$$

ただし $c_{i}(i=1,2,3,4,5), K, n$ および $m$ は材料定数 である. 式(11)のひずみエネルギー密度関数は, 微 小ひずみ領域から破断に至る大ひずみ領域まで再 現できるように, 既往のモデル ${ }^{19)}$ を拡張したもので ある. 式(11)に含まれる材料定数は, 破断実験で得 られた応力-ひずみ関係と一致するように同定した。 具体的な材料定数を表 -5 に示す. また, 表 -5 の材 料定数を用いた場合のモデルによる解析結果と, 材 料試験結果との比較を図-15に示す.

\section{c) 実験結果との比較}

図-16 に破断時の水平変位 $288[\mathrm{~mm}]$ 積層ゴム支 承に与えた場合のシミュレーション結果を示す。た だし, 図中の色は, 式(7)の $W_{d}$ の值を示している. また, 図-17 に支承の破断時の様子を示す. 図-16,

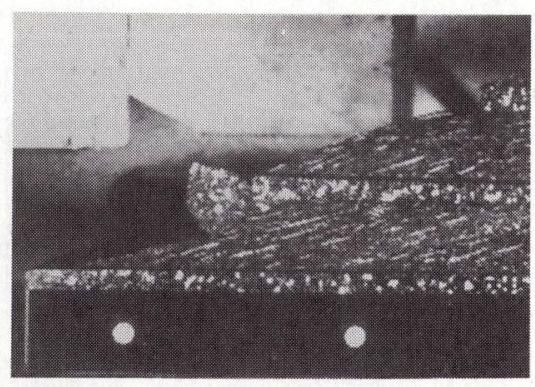

図-17 積層ゴム支承の載荷実験における破断時の状態

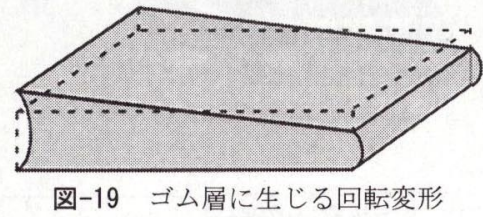

図-17をみると，実際に実験で破断している箇所に おいて $W_{d}$ が最大となっていることがわかる，その 場所においては， $\sqrt{W_{d}}=17.3$ であり，この值は材料 試験結果でのばらつき， $17.1 \leq A_{F} \leq 22.4$ を考慮する と, 下限值に近い值ではあるものの範囲内に入って いる.

\section{5. 積層ゴム支承の破断に関する解析解}

\section{（1）複合変形のひずみ場}

\section{a) 鉛直および回転変形におけるひずみ}

図-18 のような高さ $t_{0}$, 平面寸法 $a \times b$ のゴム層を 考える. 著者らは,このゴム層に一定の鉛直変形 $\Delta z$ が生じる場合の圧力場が以下のような解析解で表 現できることを示した ${ }^{11)}$.

$$
p_{C}=\sum_{n=1}^{\infty} \frac{q_{n}}{\gamma_{n}^{2}}\left\{\frac{\sinh \gamma_{n} y+\sinh \gamma_{n}(b-y)}{\sinh \gamma_{n} b}-1\right\} \sin \frac{n \pi}{a} x
$$

$こ こ に$

$$
\begin{gathered}
q_{n}=-\frac{24 G}{n \pi t_{0}^{3}}(1-\cos n \pi) \Delta z \\
\gamma_{n}=\sqrt{\left(\frac{n \pi}{a}\right)^{2}+\frac{3 G}{\chi t_{0}^{2}}}
\end{gathered}
$$

である.上式において $G$ はゴムのせん断弾性係数, $\chi$ は压力と体積変化率 $J$ を以下のように関連付け る定数である.

$$
-\frac{p_{C}}{2}=2 \chi(J-1)
$$

一方, 支承に図-19 のような回転変形 $\theta_{R}$ が生じる 
場合には, ゴム層内の圧力場 $p_{R}$ は, 次のように近 似できる。

$$
\begin{aligned}
& p_{R}=\sum_{n=1}^{\infty} \frac{q_{n}}{\gamma_{n}^{2}}\left\{\frac{\sinh \gamma_{n} y+\sinh \gamma_{n}(b-y)}{\sinh \gamma_{n} b}-1\right\} \sin \frac{n \pi}{a} x \\
& こ こ に \\
& q_{n}=-\frac{a \beta}{n \pi}(1+\cos n \pi) \\
& \beta=-\frac{12 G}{t_{0}^{3}} \tan \theta_{R} \cong-\frac{12 G}{t_{0}^{3}} \theta_{R}
\end{aligned}
$$

以上のような圧力場が生じる場合において, ゴム層 は鉛直方向に放物線形状に変形し, ゴム層の上下端 面に図-20 のようなせん断変形が生じる.このとき, 力の釣り合いから変形と圧力場には以下のような 関係が成立する.

$$
\begin{aligned}
& \frac{\partial p}{\partial x}=-8 h_{x} \frac{G}{t_{1}^{2}} \\
& \frac{\partial p}{\partial y}=-8 h_{y} \frac{G}{t_{1}^{2}}
\end{aligned}
$$

上式に式(12)あるいは式(15)の圧力場を用いると, 鉛 直変形ならびに回転変形において, 端面に生じるせ ん断変形場を求めることができる.

\section{b）圧縮変形とせん断変形によるひずみ}

ゴム層が，鉛直方向に変形を受けると，せん断 ひずみを生じる．式(17)および図-20より，ゴム層 が鉛直に変形することにより生じる $x$ 方向のせん 断ひずみ $\gamma_{c x}$ は，上下の端面において最大となり

$$
\gamma_{c x}=\frac{4 h_{x}}{t_{1}} \cong-\frac{t_{0}}{2 G} \frac{\partial p_{c}}{\partial x}
$$

となる。

一方， $x$ 方向にせん断変位 $u$ を受けると支承に生じ るせん断ひずみ $\gamma_{s}$ は, ゴム層の変形を単純せん断変形 して近似すると

$$
\gamma_{s}=\frac{u}{N t_{0}}
$$

を得る．ただし $N$ はゴム層数， $t_{0}$ はゴム層 1 層あ たりの厚さである.ここに式(19)の $\gamma_{s}$ は, 材料中 において一定となるが, 式(18)の $\gamma_{c x}$ は水平座標 $(x, y)$ の関数であり, その絶対值は $(0, b / 2)$ および $(a, b / 2)$ で最大となる.

\section{c）回転変形とせん断変形によるひずみ}

次いで回転変形とせん断変形が同時に起こる場 合を考える．ただし回転変形は，y軸と平行な軸 回りに生じ, せん断変形は $x$ 方向に変位 $u$ だけせん 断変形している場合を考える.

回転変形に生じる $x$ 方向のせん断ひずみ $\gamma_{r x}$ は, 式(20)と同様に

$$
\gamma_{r x}=\frac{4 h_{x}}{t_{1}} \cong-\frac{t_{0}}{2 G} \frac{\partial p_{R}}{\partial x}
$$

となる. 一方, せん断変形については, 式(19)を用 いる.

\section{（2）破断を予測するための解析解}

上述した複合変形において求めたせん断ひずみ を提案した破壊基準に適用し，破断を判定するため の簡易式を構築する。ただし，ここでは各変形から 得られるせん断ひずみは，連成せず重ね合わせるこ とができるものと仮定する．また，せん断変位 $u$ は, 正の值としても一般性を失わないため $u \geq 0$ とする.

\section{a）圧縮変形とせん断変形を受ける場合の解析解}

圧縮変形とせん断変形を同時に受ける場合には, 式(20)および式(19)を式(9)に代入し，破断が最も起 こりやすい場合を考慮すると，

$$
\max _{0 \leq x \leq a, 0 \leq y \leq b}\left\{\gamma_{s}+\gamma_{c}(x, y)\right\}^{4}=\left\{\gamma_{s}+\left.\gamma_{c}\right|_{x=0, y=b / 2}\right\}^{4} \leq A_{F}^{2}
$$

を得る.ここに

$$
\begin{gathered}
\left.\gamma_{c}\right|_{x=0, y=b / 2}=\frac{12 F_{Z}^{(B)}}{a t_{0}^{2}}\left(\frac{C}{C_{c}}\right) \\
C=\sum_{n=1}^{\infty} \frac{2}{\zeta_{n}^{2}}\left(1-\frac{1}{\cosh \zeta_{n} b / 2}\right) \\
C_{c}=\sum_{n=1}^{\infty} \frac{96 G a}{t_{0}^{3}\left\{(2 n-1) \zeta_{n} \pi\right\}^{2}}\left\{b-\frac{2\left(1+e^{-2 \zeta_{n} b}\right)-4 e^{-\zeta_{n} b}}{\zeta_{n}\left(1-e^{-2 \zeta_{n} b}\right)}\right\} \\
\zeta_{n}=\sqrt{\left\{\frac{(2 n-1) \pi\}^{2}}{a}\right\}^{2} \frac{3 G}{\chi t_{0}^{2}}}
\end{gathered}
$$

である。

\section{b）圧縮変形とせん断変形を受ける場合の解析解}

回転変形と圧縮変形を同時にうける場合には, 式(21)と同様の導出方法により,

$$
\begin{gathered}
\max _{0 \leq x \leq a, 0 \leq y \leq b}\left\{\gamma_{s}+\gamma_{r}(x, y)\right\}^{4}=\left\{\gamma_{s}+\left|\gamma_{r}\right|_{x=0, y=b / 2} \mid\right\}^{4} \leq A_{F}^{2} \\
\text { ただし, } \\
\left|\gamma_{r}\right|_{x=0, y=b / 2} \mid=\frac{6 M_{R}^{(B)}}{t_{0}^{2}}\left(\frac{C^{\prime}}{C_{R}}\right) \\
C^{\prime}=\sum_{n=1}^{\infty} \frac{2}{\eta_{n}^{2}}\left(1-\frac{1}{\cosh \eta_{n} b / 2}\right) \\
C_{R}=\sum_{n=1}^{\infty} \frac{24 G a^{3}}{t_{0}^{3}\left(2 n \pi \eta_{n}\right)^{2}}\left\{b-\frac{2\left(1+e^{-2 \eta_{n} b}\right)-4 e^{-\eta_{n} b}}{\eta_{n}\left(1-e^{-2 \eta_{n} b}\right)}\right\} \\
\eta_{n}=\sqrt{\left(\frac{2 n \pi}{a}\right)^{2}+\frac{3 G}{\chi t_{0}^{2}}} \\
M_{R}^{(B)}=C_{R} \frac{\theta_{R}^{(B)}}{N}
\end{gathered}
$$

である。 


\section{（3）実験結果および既往の設計式との比較}

上述した破断に関する式(21)の妥当性を検討する ために, 前述した積層ゴム支承の破断実験結果, お よび既往の設計式との比較を行った.

\section{a）支承の破壊に関する既往の設計式}

既往の設計式としては，文献 20）における「局所 せん断ひずみの照査」の式を用いる. 具体的には, 以下のようなものである.

$$
\bar{\gamma}_{S}+\bar{\gamma}_{C}+\bar{\gamma}_{R} \leq \frac{\bar{\gamma}_{U}}{f_{S}}
$$

ここに $\bar{\gamma}_{U} ， f_{S}$ は，それぞれゴムの破断ひずみ，お よび安全率である。また， $\bar{\gamma}_{S}, \bar{\gamma}_{C}$ および $\bar{\gamma}_{R}$ は，そ れぞれ水平変形によるせん断ひずみ, 鉛直変形によ るせん断ひずみ，および回転変形によるせん断ひず みである. $\bar{\gamma}_{s}, \bar{\gamma}_{C}$ については次式で与えられる.

$$
\begin{gathered}
\bar{\gamma}_{S}=\frac{u}{N t_{0}} \\
\bar{\gamma}_{C}=K_{C} S \frac{\delta_{V}}{N t_{0}}
\end{gathered}
$$

ただし $u, \delta_{V}$ はそれぞれ支承の水平変位および鉛直 変位, $S$ は 1 次形状係数, また, $K_{C}$ は支承の平面 形状に関する定数で矩形断面の場合には 8.5 である

ここでは，実支承での破壊を対象としていること から $f_{S}=1.0$ とし, 支承に生じる水平変位 $u$ として 載荷実験で与えた水平変位を用いた。 また, 鉛直変 位 $\delta_{V}$ としては，載荷実験で与えた鉛直荷重 $F_{V}$ を用 いて次式 ${ }^{20)}$ から算出した.

$$
\delta_{V}=\frac{F_{V}}{K_{V}}
$$

ただし

$$
\begin{gathered}
K_{V}=\frac{A_{R} E_{A}}{N t_{0}} \\
E_{A}=\left(3+6.58 S^{2}\right) G
\end{gathered}
$$

ここに $A_{R}$ は水平変位 $u$ での有効支圧面積である.

なお，支承の破断実験においては，ゴム層の曲げ 変形の影響により, 中間鋼板にわずかながら回転変 形も併せて生じている. しかし，この回転変形は， 実験において陽な形で与えたものではなく，各層に おいてその値も異なることから，式(25)を用いるに あたり，ゴム層の曲げによる回転変形の影響は考慮 せず， $\bar{\gamma}_{R}=0$ とおく．同様に式(21)においても回転 変形の影響は考慮してない。

\section{b) 比較結果と考察}

まず，式(26), 式(27)を用いて既往の設計式におけ る $\bar{\gamma}_{S}, \bar{\gamma}_{C}$ を計算するとそれぞれ $3.20,4.28$ であり， その結果, 式(25)の左辺は 7.48 となる. 特に鉛直変 形によるせん断ひずみの割合が大きいのは, 対象と
した積層ゴム支承の 1 次形状係数が比較的大きいた めと考えられる。一方, 式(25)右辺は, 文献 20)より $\bar{\gamma}_{U}=5.00$ となっている.このことから,ここで対象 とした支承については，既往の設計式が破壊ひずみ を約 1.5 倍過大に評価していることになる．なお， 実際の設計においては, 地震時の照査において安全 率を $f_{s}=1.2$ とすることから, さらに過大評価して いることになる.

次いで，破断時の変位を式(21)の左辺に代入する と, 式(21)を満足する最小の $A_{F}$ は18.4 となる. 一方, ゴム材料の破断実験での結果から求めた $A_{F}$ の值は, $17.1 \leq A_{F} \leq 22.8$ である.このことから $A_{F}$ のばらつ きの範囲を考慮すると, 式(21)は材料試験結果の範 囲内に入っており，支承の破断を説明できている ことがわかる.

今後, 異なる形状およびサイズを有する支承や, 他のゴム材料を用いた支承にいついても, 本式の妥 当性を異なる検討する予定である.

式(23)については, 既往の実験結果がないため, 現在のところその妥当性について検討していない， 支承の回転変形に関する載荷実験は実施自体が非 常に困難であることから有限要素モデルなどを用 いて解析解と比較検討することを考えている.

\section{6. まとめ}

本研究では, 画像解析を応用してゴム材料の破断 特性を把握し，材料および積層ゴム支承の破壊を予 測するためのモデルを構築することを目的とした. 得られた知見は，以下のとおりである.

1）単軸引張り試験およびせん断試験を行い，ゴム 材料の破断特性を把握した。 その結果, ゴム材 料の破断特性は速度依存性が非常に小さいこと， および試験片により最大 $10[\%]$ 程度のばらつき を有することがわかった。

2）材料試験結果を基に，ゴム材料の破断を予測す るためのモデルを提案した. 本モデルはひずみ の不変量をベースとしたモデルであり, 破断時 のひずみ量のばらつきを考慮すると，ここで対 象とした天然ゴム材料のせん断および引張り変 形については，材料試験結果を説明できること がわかった．また，含まれる材料定数が 1 つで あるため, 引張り試験結果のみを用いることで モデルを利用することが可能である.

3）積層ゴム支承の破断実験結果と，提案した破壊 基準を用いた有限要素モデルに取り入れた解析 
結果を比較した。その結果，提案した破壊基準 により，対象とした支承については破断を予測 できることがわかった。

4）積層ゴム支承の変形に関する既往の解析解と, 提案した破壊基準とを組み合わせ，支承の破断 を評価するための式を構築した．本式と支承の 破断実験結果とを比較したところ対象とした支 承については破断を予測できることがわかった。

以上のように本研究では, 天然ゴムを対象として 材料の破断特性を把握し, それを予測するためのモ デルを提案した．また，それを設計に応用するため の解析解を提案した。これらの結果は, 積層ゴム支 承の限界性能を合理的に予測する上で有用なもの である. 今後，他のゴム材料についても同様の検討 を行い,ここで提案したモデルの妥当性を検討して いくつもりである.

謝辞 : 材料の破断試験に用いた試験体の設計・製作 ならびに積層ゴム支承の破断実験では，日本鋳造 （株）の森重行雄氏に協力して頂きました．ここに 記して謝意を表します。

\section{参考文献}

1) 吉田純司, 阿部雅人, 藤野陽三 : 兵庫県南部地震に おける阪神高速松の浜免震橋の地震時挙動, 土木学 会論文集, No.626/I-48, pp.37-50, 1999.7.

2) R.I.スキナー, W.H.ロビンソン, G.H.マックベリー 著, 川島一彦, 北川良和監訳 : 免震設計入門, 鹿島 出版会, 1996.

3）藤田隆史, 池永雅良, 下田郁夫 : 鉛プラグ内蔵型積 層ゴムの履歴復元力特性と破断限界に関する実験的 研究, 日本機械学会論文集 (C 編)， 57 巻 533 号, pp.76-81, 1991.

4) 藤田隆史, 藤田聡, 鈴木重信, 芹沢利和: 建物免震 用の積層ゴム支承に関する実験的研究（第 3 報, 100 トン用積層ゴムの破断実験, 日本機械学会論文集（C 編）， 54 巻 507 号, 1988.

5) 多田英之, 多田羅史郎, 森田健二: 実大 Isolator に関 する実験研究, 日本建築学会九州支部研究報告第 26 号, pp.137-140, 1982.
6) 社団法人 日本道路協会 : 道路橋示方書（V 而震設 計編）・同解説，丸善， 1996.

7) Kausch, H.H.: Polymer fracture; $2^{\text {nd }}$ revised ed, Springer Verlag:Berlin, Heidelberg, Germany, 1987.

8) Treloar, L.R.G.: The physics of rubber elasticity; $3^{\text {rd }}$ ed, Larendon press, Oxford, 1975.

9) Pidaparti, R.M.V., Yang, H.T.Y. and Soedel, W.: Modeling and Fracture Prediction of Single Ply Cord -Rubber Composites, Journal of Composite Materials, Vol.26, No.2, pp.152-170, 1992.

10）吉田純司, 阿部雅人, 藤野陽三, Lewangamage, C.S.: 画 像解析を利用した連続体の変形場の計測手法, 土木 学会論文集, No.710/I-60, pp.165-179, 2002.

11) 吉田純司, 阿部雅人, 藤野陽三 : 高減衰積層ゴム支 承の 3 次元有限要素解析法, 土木学会論文集, No.717/I-61, pp.37-52, 2002.

12) Bathe, K.J.: Finite element procedures, Prentice-Hall, 1996.

13) Press, H.W., Teukolsky, A.S., Vetterling, T.W. and Flannery, P.B., 丹慶勝市, 奥村晴彦, 佐藤俊郎, 小 林誠訳：Numerical Recipes in C [日本語版]，技術評論 社, 1994.

14) Raffel, M., Willert, C. and Kompenhans, J.: Particle Image Velocimetry, Springer-Verlag, 1998.

15）日本工業標準調査会: 加硫ゴム物理試験方法, JIS -K6301, 1983.

16) AASHTO: Guide Specification for Seismic Isolation Design, Washington DC, 1999.

17) 久田俊明 : 非線形有限要素法のためのテンソル解析 の基礎，丸善， 1992.

18) 吉田純司, 阿部雅人, 藤野陽三: 高隇衰ゴム材料の 構成則, 土木学会論文集, No.710/I-60, pp.209-224, 2002.

19）山下義裕, 川端季雄: 補強ゴムのひずみエネルギー 密度関数の近似式，日本ゴム協会誌，第 65 巻，第 9 号, pp.517-528, 1992.

20）建設省：道路橋の免震設計法マニュアル（案），（財） 土木研究センター, 1992. 


\section{FAILURE BEHAVIORS OF RUBBER MATERIAL AND THEIR MODELING}

\section{Junji YOSHIDA, Masato ABE, LEWANGAMAGE Chamindaral Sujeewa and Yozo FUJINO}

Mathematical models of the failure behaviors of a rubber material and the laminated rubber bearing are studied. At first, the mechanical behaviors of rubber failure are investigated through shear and tension experiments of the material. In these experiments, an image processing is utilized to trace the deformation field of the specimens accurately. Then, based on the experimental results, a failure criterion is proposed and it is verified in comparison with the results of the failure experiment of a laminated rubber bearing. Finally, utilizing the proposed failure criterion, design equation for the failure of laminated rubber bearing is proposed. This equation also shows good agreement with the experimental result of a bearing. 